\title{
La alameda, un jardín público de árboles y agua. Origen y evolución del concepto/
}

\section{The Alameda, a Public Garden with Trees and Water. Origin and Evolution of the Concept}

\author{
Antonio Albardonedo Freire \\ Universidad de Sevilla \\ Universidad Autónoma de Chile
}

El presente trabajo constituye una compilación de fuentes historiográficas sobre el origen, la definición del concepto de alameda y el significado urbanístico de esta nueva tipología de jardín de árboles, la alameda, que desde el reino de España se difundió por todo el Imperio. En él se realiza un recorrido por la jardinería ejecutada con árboles, desde el Mundo Clásico hasta la Edad Moderna, prestando especial atención a los precedentes de este tipo de jardines.

Palabras Clave: Historia del Urbanismo; Teoría del Urbanismo; Jardines públicos; Jardines de Árboles; Alamedas; Edad Antigua; Edad Moderna; Europa; España.

The aim of this study is to offer a compilation of historiographical sources about the origin, the concept and the urbanistic significance of the newly born type of treegardens, «la alameda» (promenade). These new gardens flourished and spread during the Spanish empire. It is a travel through the gardening based on trees, from the Classical period to the Modern Age, paying special attention to the foregoing facts that led to this type of gardens.

KeYwords: History of Urbanism; Theory of Urbanism; Public gardens; Trees gardens; Alamedas; Old Age; Early Modern; Europe; Spain. 
Los estudios sobre las alamedas se han publicado en España y en Francia durante las tres últimas décadas. En España, algunos estudios se centran en las características de esta tipología. Entre ellos destacan los trabajos de Concepción Lopezosa Aparicio sobre el paseo del Prado de Madrid, proyecto realizado para la entrada triunfal de doña Ana de Austria con ocasión de su matrimonio, y que ha llegado a nuestros días profundamente transfigurado por las reformas de los siglos XVIII y XIX. ${ }^{1}$ Las condiciones de la fundación de la alameda de Hércules de Sevilla (1574) han sido estudiadas por el autor del trabajo que se presenta en estas páginas, quien ha vinculado la génesis de la alameda con un proceso de hibridación de algunos modelos artísticos representado por el arte de la pintura y los aparatos temporales edificados para las entradas triunfales. ${ }^{2}$

La alameda sevillana es en la actualidad un jardín de árboles urbano de carácter histórico que, como tal, debería alcanzar el mayor nivel de protección patrimonial como jardín histórico, ya que el conjunto ha llegado hasta nuestros días sin radicales transformaciones. Aunque en origen se concibió como homenaje a la nueva dinastía de los Habsburgo, fue un espacio de clara función urbanística, que al tiempo cumplía un importante papel recreativo para el ocio de los ciudadanos y jardín de sociabilidad teatral y que, además, contó con contenidos simbólicos y epígrafes humanísticos, realizados por Francisco Pacheco, de la escuela de Fernando de Herrera, recientemente analizados por Solís. ${ }^{3}$

Por otra parte, estos jardines públicos de árboles en Europa, han sido estudiados por Henry W. Lawrence quien estableces sus orígenes en Italia y los Países Bajos en la década de 1540. Sin embargo, el autor no consideró el importante papel desempeñado por las alamedas españolas como modelo de gran difusión en América. ${ }^{4}$

Las relaciones entre los jardines de árboles en la península ibérica y sus coetáneos europeos no han sido definitivamente estudiadas. En efecto, sólo en las últimas décadas se han generado interesantes trabajos como los publicados por María Antonia Durán Montero, que establece la vinculación entre la alameda de Hércules en Sevilla (1574) y la de Nuestra Señora del Prado en Valladolid (1603) con los proyectos de lugares públicos america-

1 Lopezosa Aparicio, 1995, 2005 y 2008; Brandis García, 2011.

2 Lleó Cañal, 1979, 194-199; Albardonedo Freire, 1998, 2000 y 2002 (191-208); Fernández Chaves, 2012, 174-184; Paya, 2014.

3 Solís de los Santos, 2012.

4 Lawrence, 2008, 11-29. 
nos, en especial, por su paralelismo, entre las de Sevilla y de los Descalzos de Lima (1610). ${ }^{5}$ Otros autores se han centrado en la alameda Central en México (D.F.), o en la de Quito; ${ }^{6}$ y las interesantes aportaciones de Paya sobre las alamedas construidas en los estados de Flandes del Imperio Español. ${ }^{7}$ Aún sin éxito, ciertos autores han intentado demostrar que en América las alamedas surgieron de modo independiente en el continente americano, sin influencia europea alguna. ${ }^{8}$

Durante la Edad Moderna se plantaron jardines públicos en un amplio número de ciudades y villas del reino de España. Por ejemplo, se construyeron en La Haya (1550), Úbeda (paseo de la Alameda o del Pastor, ca. 1550), ${ }^{9}$ Madrid (paseo del Prado, 1578), Sevilla (alameda de Hércules, 1574), Valladolid (alameda de Nuestra Señora del Prado, 1603), Segovia, Jaén, Baeza, y Cazorla. ${ }^{10}$

De hecho, los primeros ajardinamientos de espacios públicos se constatan en el reino de España, de modo que, pese a que desde la Antigüedad la concepción de la ciudad ideal incorpora espacios públicos con árboles, en otros estados de Europa su construcción se vio demorada hasta el siglo XVIII por la falta de recursos.

\section{Paralelismos entre las alamedas renacentistas españolas y los entornos arbolados de la Antigüedad}

Las primeras reflexiones escritas documentadas sobre el valor de los árboles y los bosques corresponde a la Antigüedad, que, como declaraba Plinio, «árboles y bosques se concebían como el mayor don conferido al hombre»; según el autor, de los bosques se obtenía sustento, descanso confortable gracias a sus hojas secas, y vestimenta, ${ }^{11}$ además de otros valores materiales o económicos imprescindibles para el hombre, como la energía obtenida con la combustión de madera y las piñas, la alimentación con la

5 Durán Montero, 1985

6 Castro Morales, 2004; Duarte, Sánchez y Ugalde, 2001; Herrera, 1984, 393-394.

7 Paya, 2014.

8 Muñoz Rebolledo e Isaza, 2001; Segawa, 2004.

9 Albardonedo Freire, en prensa.

10 Veiga, 1973, 68-69; Aguilar Diosdado y García León, 1988; Moreno Mendoza, 2005; Durán Montero, 1985, 179-181; Pareja Delgado, 1989; Uceda Ureña y Peragón López, 2003; Contreras y López de Ayala, 1974; Van Den Berg, 2001.

11 Plinio, 1629, XII, 1; Plinio, 2010, v. 3, 9. 
fruta y numerosas sustancias químicas obtenidas de las resinas. El autor recordaba agradecido que con su madera se hizo posible surcar los mares, construir viviendas, tallar imágenes y la savia de ciertos árboles permitió el disfrute del aceite y el vino. ${ }^{12}$

Los griegos y romanos admiraban el gran tamaño de los árboles y se ofrecían como ofrenda incruenta a los dioses. Se llegó a pensar que en estos gigantes se asentaban las divinidades, y en ellos realizaban los cultos; efectivamente, el mismo Plinio el Viejo nos dejó escrito: «Los árboles fueron templos de la divinidad, y todavía en la actualidad, a la antigua usanza, los sencillos campesinos le dedican a un dios el árbol que más descuella». ${ }^{13}$

El árbol fue considerado en todas las culturas el elemento vegetal más difícil de poseer, admirado por su larga permanencia en el mismo lugar, por el lento crecimiento hasta alcanzar su extraordinario tamaño ${ }^{14}$ y por sus gratificantes efectos sensoriales (el placer visual de su aspecto, ${ }^{15}$ la sensación de su sombra, el sonido de los susurros, el olor de las resinas y el gusto de sus frutos).

Las razones por las que los bosquetes arbolados proliferaron a partir del mundo clásico fueron las siguientes: ya en la Grecia clásica, se propugnaba el disfrute y la posesión de grandes ejemplares o conjuntos arbóreos, por su aristocrático porte y por valorarse el tiempo que precisaba para alcanzar la envergadura conveniente. En consecuencia, el conocimiento sobre el cultivo de los árboles también fue muy valorado, ${ }^{16}$ y se orientó entre otras cosas a organizar con planificación geométrica los árboles. Especialmente, eran en gran medida estimados los bosquetes ornamentales con alineaciones de árboles de carácter geométrico, entornos urbanos que proliferaron por los escasos cuidados que los árboles precisaban una vez enraizados. También por sus beneficios como entornos sociales, y que permitían conformar áreas de paseos de sombra para el disfrute, e incluso (como sucedió en el mundo clásico) para entrenamientos de atletas; de hecho, en Atenas y Roma se dedicaron amplias superficies con árboles, con una organización generalmente ortogonal.

12 Plinio, 1629, XII, 4; Plinio, 2010, v. 3, 13.

13 Plinio, 1629, XII, 3; Plinio, 2010, v. 3, 11.

14 Idem. Otras referencias a la gran altura de los árboles en Plinio, 1629, VIII, 9; IX, 9; X, 3; VI, 32; XVI, 40.

15 De los árboles se ha dicho con razón que son los únicos cadáveres bellos de la naturaleza.

16 Plinio, 1629, XII-XIX. 
En las alamedas también se buscó el contacto con la naturaleza dentro de la ciudad, y un espacio en el que el paseo fuera el fin principal; se creía, no sin razón, que ambas actividades aportaban a los humanos beneficios físicos y psíquicos. De hecho, no era nueva esta opinión, pues ya desde la Antigüedad se conocían estas ventajas saludables y Vitruvio, en su tratado De Architectura (siglo I d.C.), nos dejó claros comentarios sobre el particular:

El descubierto que se dexa en el medio entre los pórticos parece debe vestirse de plantas. Su paseo al descubierto es muy agradable, singularmente para la vista [...]. Asi mismo, tomando el cuerpo calor con el movimiento del paseo, y desecando el ayre los humores de los miembros, alivia la plenitud, y evacua las superfluidades, disipando lo que no puede llevar el cuerpo. ${ }^{17}$

Las alineaciones de árboles en los bordes de los caminos y en los bosquetes de la Antiguiedad, serán los que en el siglo XVI permitieron concebir las alamedas en España durante reino de Felipe II, con el fin de generar sombra, factor determinante en la proliferación de las alamedas, ya que permitían dar agradable cobijo a grandes concentraciones humanas. Las alamedas de la Edad Moderna eran paseos formados por varias calles de árboles que existían gracias a la imprescindible presencia del agua de riego. Y sin duda, los fines buscados en ellas era disfrutar de la sombra para distintas actividades, entre ellas el entrenamiento solitario y en grupo, el ejercicio atlético en todas las formas posibles, incluso para los caballistas. En las alamedas también se producía el descanso sentado, y la contemplación de los ciclos vitales de la naturaleza, que ayudaba a la relajación psíquica y al estudio. A esto se sumaba las múltiples formas de relación social, marco perfecto para ver o ser visto, además de para cortejo amoroso que se producían entre iguales. En efecto, a las alamedas públicas acudían los distintos estamentos sociales a pie o en coche de caballos, reuniéndose en torno a la charla y al son de la música. Las distintas ocasiones para reunirse en las alamedas eran el buen tiempo, las devociones, la fiesta y el mercado, entre otras.

Los árboles protagonistas de las alamedas promovidas en España durante el reinado de Felipe II fueron especies de álamos (Populus alba, Populus Nigra y Populus Tremula), aunque ocasionalmente también surgieron otras con diversos géneros de árboles. Por el contrario, en la

17 Vitruvio, 1787, v. 9, 38, 127; Grimal, 1984, 80. 
Antigüedad clásica, tanto en Grecia como en Roma, los árboles más característicos para los mismos espacios arbolados, públicos y privados, habían sido los plátanos de sombra (Platanus Orientalis). Sobre estos géneros de árboles de sombra, álamo y plátano, Teofrasto los incluía en el mismo grupo, aquel que consideraba de rápido crecimiento si se cultivaba en un terreno bien regado:

Si se aprovechan terrenos idóneos y se les prestase los cuidados pertinentes, se reproducirán igualmente, como ocurre con los árboles del bosque y del pantano, es decir, el plátano, el sauce, al álamo temblón, el álamo negro y el olmo; porque todos estos árboles y otros semejantes crecen deprisa y con toda facilidad. ${ }^{18}$

En las alamedas la elección de la especie del álamo estuvo ligada a su rápido crecimiento, especialmente cuando crecía en lugares pantanosos, y a la facilidad para reproducirlos. Además contribuyó a la elección de esta especie, la extraordinaria carga mitológica del álamo en la Antigüedad, pues estaba estrechamente vinculado con Hércules, hijo de Zeus. Plinio el Viejo nos lo contó de la siguiente manera:

Hay especies arbóreas que gozan de permanente protección por estar consagradas a determinadas divinidades, como el roble a Júpiter, el laurel a Apolo, el olivo a Minerva, el mirto a Venus y el álamo a Hércules. ${ }^{19}$

En la mitología clásica también existen importantes referencias a los árboles, un caso vinculado con los álamos es el de la ninfa Leuce (en griego llamada «la Banca» o «álamo blanco») fue amada por Hades, y con él vivió en su reino. Después del fallecimiento de Leuce, Hades la metamorfoseó en un álamo blanco (Populus Alba) de los Campos Elíseos, lugar donde se pensaba que los piadosos pasarían su vida futura. Asimismo se decía que Hércules, después de salir del reino de Hades (los Infiernos) y de haber vencido al Can Cerbero, el perro de Hades, se hizo una corona de álamo blanco recogido en los Campos Elíseos. El escritor Mario Servio Honorato nos lo contó así:

Populus alcidae gratissima quia ea velatus ab inferis rediit: quam Homerus $\alpha \chi \varepsilon \rho \omega \hat{\delta} \delta \alpha$ dicit, ab Acheronte ad superos translatam; qua corona usus, duplici colore foliorum, geminos labores (superorum) inferorumque testatus est. De hac sane arbore fabula

18 Teofrasto, 1988, III, 1, 149-150.

19 Plinio, 1629, XII, 1, 3; Plinio, 2010, v. 3, 11-12. 
talis est; Leuce, Oceani filia, inter nymphas pulcherrima fuit; hanc Pluton adamavit et ad inferos rapuit. quae postquam apud eum completo vitae suae tempore mortua est, Pluton tam in amoris, quam in memoriae solacium in Elysiis piorum campis, Leucen nasci arborem iussit, ex qua, sicut dictum est, Hercules se, revertens ab inferis, coronavit. ${ }^{20}$

Asimismo, Pausanias dejó testimonio de que Hércules trajo el álamo blanco desde Tesprotia de Epiro a Atenas, y recordó que con ramas de álamo se coronaba a los vencedores en los juegos de Olimpia. ${ }^{21}$ Para finalizar esta relación de escritos clásicos, recordaremos que Virgilio nos indicó que Hércules se había ceñido la cabeza con ramas de álamo en señal de triunfo, tras dar muerte a Caco en la cueva del monte Aventino. ${ }^{22}$

Con este conjunto de fuentes escritas tenemos oportunos argumentos para valorar la decisión tomada en Sevilla de dedicar la nueva alameda a Hércules, mítico fundador de la ciudad. ${ }^{23} \mathrm{El}$ nombre debió ser refrendado por los munícipes cuando la mandaron plantar en 1574, basándose en la extraordinaria carga mitológica que relacionaba a Hércules con los álamos, y al mítico fundador de Sevilla con la dinastía Habsburgo.

Podemos concluir este apartado afirmando que el álamo es uno de los árboles más vinculados con la mitología clásica, además de formar parte principal del ceremonial en el culto a Hércules de los templos de Roma. ${ }^{24}$ Asimismo, en el concepto de alameda se dan los siguientes elementos esenciales: el ser un espacio con planta generalmente rectangular, definido por las hileras de árboles; la abundancia de agua que daba vida por medio de fuentes y acequias; y las calles de ida y vuelta para el paseo. Además, algunas construcciones complementaban el espacio: desde el siglo XVI las acequias, portadas y ciertas símbolos religiosos; ya desde el siglo XVIII se generalizaron los bancos para el descanso y el palco para los músicos. En ocasiones se sumaban otras construcciones monumentales que completaban el adorno, de acuerdo a la estética y al poder económico de cada época. A las alamedas se les otorgaba un topónimo que frecuentemente estaba vinculado a ciudadanos ilustres, a los que se rendía homenaje.

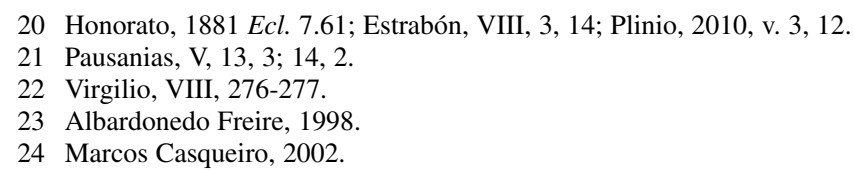




\section{Los jardines de árboles alineados, públicos y privados, del mundo clásico}

Frente a las escasas publicaciones sobre la jardinería clásica griega donde apenas contamos con el capítulo que Gothein dedicó a Grecia, en una historia general de la jardinería de 1914, y estudios arqueológicos concretos como por ejemplo el que realizó Thompson del templo de Hefaistos de 1937. ${ }^{25}$ Por el contrario sobre la jardinería romana contamos con estudios generales importantes como el precursor trabajo de Grimal de 1944, y con la avanzada investigación arqueológica de la ciudad de Pompeya llevada a cabo por Jashemski desde 1979 o los estudios de casos concretos como el de Önnerfors sobre el pórtico de Octavia. ${ }^{26}$

La evidencia arqueológica muestra que existieron pequeñas reservas de espacios centrales con vegetación en el ágora de las ciudades de la Grecia clásica. Para la historia de la jardinería, la cultura griega clásica no posee un estilo de jardín tan definido como el estilo que se practicó en los jardines del antiguo Egipto. Fue manifiesta la diferencia entre el esplendor en las demás artes griegas y su relativa debilidad en materia de jardines. Marie Luise Gothein, en su Geschichte der Garden Kunst ${ }^{27}$ explicó que la democracia griega no favoreció la concentración de grandes fortunas. Sin estas últimas riquezas no se pudieron crear ni mantener grandes jardines particulares. No obstante, la democracia no fue incompatible con la ordenación de grandes espacios públicos urbanos, reservados para el solaz de los ciudadanos.

La sede del poder político de las ciudades de Grecia no se encontraba aislada en un edificio, ni lejos de la vida ciudadana, sino en el ágora, en el centro de la ciudad, y generalmente próximo crecía un gran árbol o un conjunto de ellos. ${ }^{28}$ Con el progreso de las ciudades esas arboledas se fueron organizando como jardín público, donde la geometría reinaba en la disposición arborescente, alineada y ordenada por el hombre, quien bajo su sombra encontraba en los meses calurosos el mejor amparo.

En Atenas hubo una creciente preocupación por incluir en plazas públicas los árboles. Estos gigantes vegetales siempre satisfacían las necesidades que después se buscaron en los distintos tipos de jardín: verdor,

25 Gothein, 1914; Thompson, 1937.

26 Grimal, 1944; Jashemski 1979; Önnerfors, Olinder y Tengström, 1974.

27 Gothein, 1979, I, 53; Carroll-Spillecke, 1992.

28 Baridon, 2004, 180. 
olor, sombra, orden del espacio, frutos comestibles, definición del lugar por la presencia de una variedad u otra arbórea y ciertas variedades con claros significados mitológicos, en torno a los que se definieron claros valores simbólicos. Sin embargo, en los proyectos más antiguos parece que no se puso mucho énfasis en la correcta disposición arbórea. ${ }^{29}$ No obstante, pronto en el entorno de los templos de Atenas y de otras ciudades se plantaron ordenadamente árboles de acuerdo con las líneas que marcaban los ejes de las columnas de los pórticos de los templos, y con la misma separación que el espacio del intercolumnio. Así se ha podido constatar en las excavaciones arqueológicas de algunos templos, especialmente en aquellos que se elevaron sobre colinas rocosas. La naturaleza del lugar obligaba a que para plantar los árboles tuvieron que abrirse pequeñas cubetas, perforando la roca del macizo y rellenándolas de tierra, con el fin de en ellas plantar los jóvenes árboles. Tales cubetas, excavadas en el s. III a.C., han sido la huella de interés arqueológico que nos ha permitido conocer la localización exacta de la plantación alrededor del templo de Hefaistos (449 y 425 a.C.), ${ }^{30} \mathrm{o}$ del santuario de Heracles en la isla de Tasos, en prefectura de Kavala en Grecia. ${ }^{31}$

En definitiva, esta plantación arbórea organizada en ciudades y áreas inmediatamente adyacentes a éstas, se utilizó como elementos definidores, por los que a través de las especies otorgar la identidad de un sitio y su función. El uso de los árboles se limitaba a los lugares de culto y enterramiento, a los gimnasios, palestras, a los centros filosóficos de la Academia y el Liceo $^{32}$ y de concentración ciudadana.

En el Liceo y en la Academia de Atenas existía un pequeño conjunto de árboles plantados en forma de paseo formado por plátanos de sombra y regados por una acequia. La primera función de estos bosquetes era servir como el espacio para la docencia, además de un lugar de esparcimiento, un complejo deportivo de entrenamiento y lugar de enterramiento de ilustres. Estrabón refirió la existencia del Liceo, de la Academia y de los demás «jardines de los filósofos». ${ }^{33}$ Fueron estos lugares de gran reconocimiento internacional y el árbol tuvo larga vida pues parece que perduró hasta el

29 Panzini, 1993, 3.

30 Thompson, 1937.

31 Launey, 1937.

32 Platón, 1988, VI, 249; Teofrasto, 1988, I, 1,7 y 90; Plinio, 1629, XII, 3, 7 y 9; Plinio, 2010, v. 3, 11, 15 y 16; Plutarco, 1990, 324; Diógenes Laercio, III, 5.

33 Estrabón, IX, I, 17. 
año 529 d.C., cuando el emperador Justiniano ordenó el cierre de todos los establecimientos de educación de Atenas. ${ }^{34}$

La tradición de disponer alineaciones de árboles, generalmente plátanos de sombra en los lugares académicos fue posteriormente adoptada por los griegos en las colonias como los plantados por Dionisio el Viejo en Regio di Calabria, en forma de paseo en recuerdo de la Academia de Platón, al igual que hicieron los romanos en los últimas décadas de la República y el Imperio. ${ }^{35}$ Ya en el siglo XV fue de nuevo revivido su uso por León Battista Alberti al proponer el paseo de la Academia como modelo en De re adificatoria (1452). ${ }^{36}$

En aquellos jardines de árboles situados en un radio de cuatro kilómetros de la Acrópolis se podían encontrar estatuas, tumbas y santuarios. Además, en ellos eran esenciales las pistas para el entrenamiento de los atletas, los paseos sombreados por árboles para la competición intelectual y la reflexión, junto con piscinas y baños. Diógenes Laercio en el siglo III d.C., al hablar de la Academia de Platón dejo escrito que era «un gimnasio fuera de las murallas, en un bosque llevaba el nombre de Hecademus, un héroe». ${ }^{37}$ Plutarco fue más explícito al recoger la empresa de embellecimiento de la ciudad de Atenas con grandes árboles y la dotación de agua y bosques en la Academia, todo emprendido por Cimón después de la victoria sobre los persas:

[Cimón] Fue el primero en hermosear la ciudad con aquellos lugares de recreo y entretenimiento, por los que hubo tanta pasión después, porque plantó de plátanos la plaza, y a la Academia, que antes carecía de agua y era un lugar enteramente seco, le dio riego, convirtiéndola en un bosque, y la adornó con corredores espaciosos y desembarazados, y con paseos en que se gozaba de sombra. ${ }^{38}$

El mismo Platón fue quien en Fedro describió la atmósfera extraordinaria creada por un gran plátano de sombra plantado en la Academia, del cual tenemos varias referencias en el mismo libro. ${ }^{39}$ Otro gran plátano también muy admirado creció junto al canal del Liceo de Aristóteles a consecuencia del abundante riego. Teofrasto escribió que alcanzó muy pronto una gran envergadura: «Así el plátano que hay en el Liceo, a orillas del

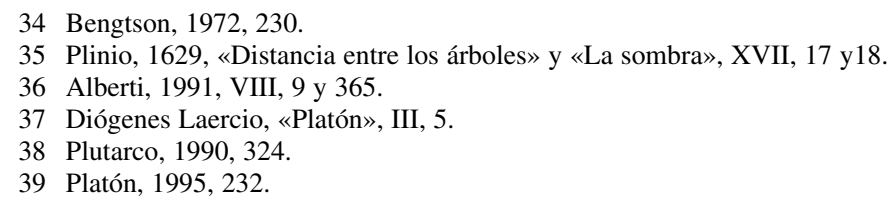


acueducto, cuando todavía era joven, extendía sus raíces a una distancia de 33 codos porque tenía espacio y alimento». ${ }^{40}$

Bajo los árboles se impartía la docencia donde creían que las ideas se percibían mejor, con mayor acogida que en una sala cerrada. Platón en Fedro sobre la Academia dejó un completo inventario de las delicias sensible que el jardín de árboles ofrecía:

SÓC. — ¡Por Hera! Hermoso rincón, con este plátano tan frondoso y elevado. Y no puede ser más agradable la altura y la sombra de este sauzgatillo, que, como además, está en plena flor, seguro que es de él este perfume que inunda el ambiente. Bajo el plátano mana también una fuente deliciosa, de fresquísima agua, como me lo están atestiguando los pies. Por las estatuas y figuras, parece ser un santuario de ninfas, o de Aqueloo. Y si es esto lo que buscas, no puede ser más suave y amable la brisa de este lugar. Sabe a verano, además, este sonoro coro de cigarras. Con todo, lo más delicioso es este césped que, en suave pendiente, parece destinado a ofrecer una almohada a la cabeza placenteramente reclinada. ¡En qué buen guía de forasteros te has convertido, querido Fedro! ${ }^{41}$

Este sistema de acequias que suministraba agua a la ciudad, regaba los árboles y atendía las demás necesidades de la Academia y el Liceo era uno de los elementos de la ciudad ideal, tal y como Platón indicó en el libro Leyes VI:

Las aguas de manantial, sean de río o de fuentes, quedarán adornadas y embellecidas con plantaciones y construcciones... Si en los alrededores hubiese un bosquecillo o un recinto consagrado será hermosamente adornado con acequias que durante todas las estaciones del año llevarán el agua a dicho santuario. En todo el paraje de este tipo los jóvenes deberán construir gimnasios para ellos mismos y para los ancianos; a estos últimos les prepararán baños termales adecuados a su edad... y acogerán benévolamente para su alivio los cuerpos de quienes se consumen en la enfermedad... acogida esta que será mucho mejor que la que podría dispensar un médico no demasiado competente. ${ }^{42}$

Como se sabe, la palestra era otra institución formativa griega dedicada a la instrucción física e intelectual y a la competición de luchadores. Todo gimnasio griego tenía que tener una palestra para entrenar a los luchadores. Una importante fuente de información es Vitruvio, quien proporcionó unas ricas noticias de los edificios griegos de la palestra, y además dio muchos detalles sobre la disposición de los paseos de árboles, destinados

40 Teofrasto, 1988, I, 7, 1 y 90.

41 Platón, 1995, 232.

42 Platón, 1988, VI, 249. 
al descanso de los atletas, y de los pórticos del jardín en los que se concentraba la vida cultural. Las descripciones de los edificios y el uso de los espacios corresponden al siglo I a.C., si bien tenemos referencias de su existencia desde el siglo V a.C. Como Vitruvio describe, la palestra era un edificio con escasos vanos abiertos hacia el exterior, de forma rectangular con pórticos sobre columnas en sus cuatro frentes. Vitruvio nos describe lo fundamental del siguiente modo:

50 Aunque en Italia no se usan las palestras, he querido sin embargo dar aqui una cabal noticia de ellas al uso de los Griegos [...] En las palestras, pues, sean sus peristilos quadrados $[\ldots]$ tendrán de largos los pórticos en rededor dos estadios [...].

52 Fuera se harán tres pórticos uno al salir de la palestra, y los otros dos que serán estadiados [...] pero junto a la pared por una parte, y junto á las colunas por otra, se dexan dos sendas no menos anchas de diez pies; y el medio tan rebaxado que se hagan dos gradas para baxar [...]. Lo llano de abaxo no será menos ancho de doce pies. De esta forma los que pasean en dichas sendas no serán incomodados en su ropa por los luchadores ungidos. Los Griegos llaman xistos á este pórtico; porque los atletas en invierno luchan en estadios cubiertos.

53 Los xistos parece deberán construirse en esta forma: entre los dos pórticos se harán parques, o plantaron plátanos; y entre ellos se construirán paseos con sus descansos de obra signia.

54 Junto al xisto y pórtico doble se dexarán los paseos descubiertos, que los Griegos llaman peridromidas, y los Latinos xistos, en los quales se exercitan los atletas; dexando el xisto cubierto aun en invierno, si el tiempo está sereno [...]. ${ }^{43}$

Buenos ejemplos de palestras se conservan en Olimpia, Epidauro, Corinto, Delfos. En Pompeya contamos con un extraordinario edificio de época romana, representativo de la traslación y adaptación del modelo griego de palestra, especialmente desde el gobierno de Octavio Augusto, cuando la educación física atlética triunfó entre los jóvenes de las familias acomodadas.

\section{El surgimiento de la jardinería como arte en Roma en el siglo I a.C.}

Los más antiguos jardines públicos de Roma eran del siglo $\mathrm{V}$ a.C., en forma de prados públicos en honor de grandes personajes. Livio en $A b$ Urbe Condita dejó importantes referencias de los dedicados a Mucio Escévola, y a Quincio Cincinato en la orilla del Tiber, con las denomina-

43 Vitruvio, 1787, «De la construcción de las palestras», V, 11, 50-54, 131-132. 
ciones de Prata Mucia y Prata Quinctia. ${ }^{44}$ En cuanto a la jardinería particular, y siguiendo el modelo griego, los romanos adoptaron el modelo de casa con modesto huerto hasta el siglo I a.C. A partir de entonces, tuvieron como ideal la casa mediterránea con jardín, tanto en la vivienda de ciudad, como en la villa suburbana, o las residencias rurales lejos de núcleos urbanos.

Coincidiendo con el surgimiento del jardín privado doméstico durante el comienzo del Imperio se formuló la pretensión, cada vez más imperiosa, de rus in urbe. Primero en el ámbito privado, y después en el espacio público se ofrecían como refugio de naturaleza en la ciudad, que entonces había alcanzado una densidad de población cada vez mayor, y también como remedio al creciente ruido que comportaba.

Entre la época de Marco Tulio Cicerón (106-43 a.C.) y la de Columela (s. I d.C.), creció el aprecio por los jardines de árboles municipales. El rus in urbe recordaba el origen campesino de los romanos, la tierra nutricia, y los bosques primitivos de pinos de las colinas de Roma, los cuales se conservaron en algunos puntos. Estos bosquetes, naturales o plantados, ${ }^{45}$ fueron las residencias aristocráticas de época imperial, como las del Palatino. Estos lugares verdes eran además el ideal de recreo de cualquier ciudadano romano. En el año 12 a.C. después del incendio del Foro, el emperador Octavio Augusto promovió un jardín de árboles; para ello mandó dejar libre una zona donde se viera la tierra natural, e hizo plantar allí un olivo, una parra y una higuera. Tres plantas que se cuidaron en representación de los alimentos básicos, y fueron los impulsores de la rus in urbe, pues despertaron en los romanos el deseo de llevar una pequeña parte de la vida rural a la ciudad. Además, en la ciudad imperial de Roma se encontraban más de ochenta jardines privados grandes de las imponentes villas y pequeños huertos de casas sencillas.

44 En Roma antigua existieron los prados públicos. En la orilla derecha del Tíber se encontraba el Prata Mucia en el lugar donde se localizaba la granja que regalaron a Cayo Mucio Escévola (Caius Mucius Cordus Scaevola), por su comportamiento valiente ante el rey enemigo Porsena. Su valentía consistió en que para no declarar ante Porsena durante la guerra contra los etruscos (507 a.C.), metió su mano derecha en el fuego para mostrar su indiferencia ante el dolor (et facere et pati fortia Romanum est, «hacer y padecer cosas fuertes es romano») según Livio, II, 12, 9; II, 9-14. Plutarco, «Vida de Publicola», 17. Y también el Prata Quinctia, donde estaba el campo cultivado por el virtuoso Lucio Quincio Cincinato (s. VI-V a.C.) según Livio, 26-29. Marco Porcio Catón y otros escritores republicanos romanos hicieron de él un arquetipo de rectitud y honradez, personificando las virtudes romanas de la República. Panzini, 1993, 3.

45 Plinio el Viejo recuerda, quizá sólo un rumor, que el primero que plantó bosques fue Gayo Mancio. Plinio, 2010, v. 3, 20. 
Los jardines de árboles romanos eran un escenario deseado por los más refinados intelectuales que en ellos se podían aislar en la calma. Las copas de los árboles sobre los muros de cierre de los jardines privados permitían imaginar al paseante la ostentación de ciertas casas de personajes de la República y del Imperio. Algunos gobernantes en la búsqueda de prestigio realizaron grandes proyectos urbanos ajardinados con árboles, que donaron al pueblo en recuerdo de su memoria. De este modo, los jardines de árboles en poco tiempo asumieron un lugar en la vida pública.

La historia de la jardinería de árboles en Roma comenzó con el jardín plantado por el militar Lucio Licinio Lúculo (117-56 a.C.) tras su retiro de la vida militar. Los jardines que promovió en su casa de Roma (ca. 60 a.C.) se conocen a través de las noticias aportadas por Plutarco en la biografía que le dedicó. ${ }^{46}$ No obstante, fue una referencia y modelo a seguir el primer gran jardín de árboles privado situado en el Campo de Marte, los horti luculliani. Lúculo lo organizó en terrazas debido a la gran irregularidad del terreno. En la terraza central Lúculo mandó plantar árboles ante un gran pórtico. Se ha propuesto que seguramente Pirro Ligorio en el grabado Antiquae urbis imago (1561) recogió los restos centenarios, o por lo menos ejemplares renovados que seguían la misma estela de aquel bosque privado, envidiado por los ciudadanos y mantenido por los gobernantes de Roma durante más de diez siglos.

Por otro lado, Cicerón en sus cartas se hizo eco del nuevo arte que estaba surgiendo en el momento, el de la jardinería, y dio detalladas descripciones de distintos jardines que él frecuentaba pertenecientes a amigos intelectuales. Con su buena pluma nos aportó el aprecio personal por el agua, el tamaño de los árboles, la sombra, el olor, la vista y el color, además de la disposición y decoración de los mismos con construcciones y esculturas. ${ }^{47}$ Estas últimas eran una novedad que en época republicana se había rehusado por ser un lujo ajeno, de procedencia oriental. Cicerón vivió el momento del cambio en el que se sustituyó el huerto anejo a la vivienda por un jardín decorado y opulento con gran aparato ornamental y escultórico.

Marco Porcio Catón (234-149 a.C.) en el libro octavo de su obra De agricultura dejó referido que en la huerta o «fundum suburbanum», pese a estar concebida como una propiedad de producción exclusivamente agrícola, en ella y por primera vez en un texto romano, se contemplaba la posibi-

46 Plutarco, «Vida de Lúculo», 39.

47 Cicerón, 1996, carta 2, 46-47. 
lidad de tener árboles decorativos y ornamentales ${ }^{48}$ Esta concepción de árboles con fines estéticos de Catón, fue adoptada por los demás teóricos romanos de la agricultura, como Marco Terrentius Varro (116-27 a.C.) y Lucius Junius Moderatus Columela (s. I d.C.).

El propio Varrón en su obra De Re rustica se hizo eco de los excesos a los que se prestaban los nuevos jardines de placer en las fincas rústicas:

Las construcciones, dijo Fundanius, influyen mucho, indiscutiblemente, sobre el cultivo cuando esta concebidas según la inteligente simplicidad de nuestros ancestros y no siguiendo las actuales ideas del lujo [...] ahora no se piensa sino en satisfacer las fantasías más extravagantes. Entonces el propietario tenía grandes construcciones agrícolas y se alojaba modestamente en la ciudad. Hoy ocurre, generalmente lo contrario. ${ }^{49}$

Y además dejó constancia de la magnitud de los grandes árboles plantados por los propietarios con fines ornamentales:

Más allá hay un bosque de alto fuste, plantado por la mano del hombre y que no deja penetrar la luz más que por debajo: un muro elevado lo rodea exactamente. Entre la columnata exterior, que es de piedra, y la interior, que está hecha de abetos muy esbeltos, hay un intervalo de 5 pies de anchura. ${ }^{50}$

Por otro lado, Columela en la obra de Res rustica,$^{51}$ dedicó todo el libro $\mathrm{X}$ a la jardinería. En él rompió con su estilo sobrio y estableció una forma poética en él infrecuente, el hexámetro, siguiendo las Geórgicas de Virgilio, que contrastaban con las indicaciones y método pragmático, en prosa, seguido en el resto del libro al hablar de ganadería y agricultura. Adoptó un estilo poético sólo para describir las emociones de la contemplación del jardín. En cuanto al contenido, Columela en su libro amplió el concepto del «huerto», proponiendo por primera vez la inclusión de un jardín ornamental autónomo. La fórmula retórica inducía a pasear por un jardín de árboles lleno de sombra, concepto que se convirtió en el verdadero pozo teórico de su poesía sobre el jardín ornamental.

La mitología y la religión en Roma daban a los campos y, sobre todo, a la vegetación de escala gigante, una dimensión filosófica, haciendo de ellos la imagen de las fuerzas de la naturaleza que se veneraba. ${ }^{52}$ Lucio Anneo

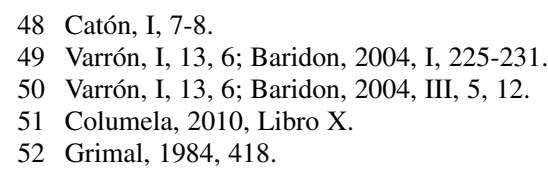


Séneca (4 a.C.-65 d.C.) conoció la primera generación de los grandes jardines estéticos, escenario de la vida relajada de los aristócratas, especialmente durante el gobierno de Nerón (54-68d.C.). Quizá por el rechazo que para él representaba esa vida, en Epistulae Morales ad Lucilium (ca. 65 d.C.) aún ensalzó un sentimiento religioso que inspiraba los grandes árboles naturales y salvajes, un estado de la cuestión que estaba ya en decadencia:

Si tibi occurrerit vetustis arboribus et solitam altitudinem egressis frequens lucus et conspectum caeli ramorum aliorum alios protegentium summovens obtentu, illa proceritas silvae et secretum loci et admiratio umbrae in aperto tam densae atque continuae fidem tibi numinis faciet. ${ }^{53}$

Los grandes jardines aparecieron no sólo en la ciudad de Roma sino también en las correspondientes a las regiones de Campania, en la Lombardía, en el Lacio, y en numerosas ciudades y villas de todo el territorio. En Roma se introdujo la influencia del Mediterráneo oriental, tanto griega como del Oriente helénico. Entre otras novedades se introdujo el arte de los jardines de árboles, con pinturas de paisajes campestre y escenas de influencia griega y de Alejandría. Asimismo se transformó la arquitectura de la casa romana que se abrió al jardín mediante los pórticos, desde donde se contemplaba el paisaje circundante..$^{54}$

\section{El primer jardín público de Roma}

El parque público más antiguo que conocemos de la ciudad de Roma es el Pórtico de Pompeyo. En su origen fue una galería porticada que rodeaba un espacio abierto intermedio ajardinado con árboles, formando parte del teatro de Pompeyo en Roma construido hacia el año 55 a.C..$^{55}$ Nos ha llegado buena información del jardín que estaba inspirado en la palestra griega y definido por tres calles de plátanos de sombra, laureles y columnas. Se trataba de un recinto ortogonal de aproximadamente 180 por $135 \mathrm{~m}$,

53 Séneca, 41, 3: «Cuando con ancianos árboles, cuya altura excediese con exceso la ordinaria, te ocurre [te encuentras] un bosque frecuentado, y que con la densidad de ramas entretejidas esconde a tu vista el cielo, aquella grandeza de la selva, lo arcano del lugar, y la admiración de la sombra tan densa y tan continua en descubierto, alguna deidad testifica a tus ojos». Moya del Baño y Gallego Moya, 2011.

54 Grimal, 1984, 440.

55 Ramallo Asensio, 2000; Gagliardo y Parker, 2006. 
definido por un eje central ordenador, perpendicular a la escena. El jardín se dividía en tres calles, la central bordeada de plátanos de sombra era la de entrada y dos laterales; en total el espacio estaba formado por cuatro líneas de árboles y columnas, todos paralelos al eje más largo.

El pórtico de Pompeyo marcó el inicio de un modelo de jardines de árboles que se consolidó en teatros construidos durante el gobierno de Octavio Augusto. Dicho pórtico perimetral tuvo las funciones de resguardo de espectadores en caso de lluvia y de almacén como mencionó Vitruvio ${ }^{56} \mathrm{y}$ con carácter representativo, como espacio adecuado para la relación de las elites locales. El pórtico se añadió en teatros donde acudía la familia imperial o el poder político y económico, como ocurría entre otros teatros en los de Volterra, Ostia y Mérida. La tipología de los pórticos se introdujo en Roma en el año 100 a.C., pasando a un tamaño monumental en la década de 80 a.C., en los edificios conmemorativos del triunfo de los generales romanos como Pompeyo que volvieron victoriosos de Oriente. ${ }^{57}$ El pórtico romano más antiguo que ha dejado evidencias arqueológicas es el pórtico Metelo del circo Flaminio, construido por Quinto Celio (146 a.C. $)^{58}$ y después dedicado por Augusto a su hermana Octavia (27 a.C.). ${ }^{59}$

Tal y como dijo Alberti, el jardín de árboles es también arquitectura, ${ }^{60}$ por ello ya antes Vitruvio se había ocupado del valor constructivo de los árboles al hablar de las formas arquitectónicas realizadas con árboles como la división del espacio, las alineaciones del pórtico de Pompeyo. Vitruvio señaló que era fácil reconocer en aquella disposición interior modelos orientales, como las hileras de plátanos simétricas usados en los jardines sagrados de Oriente de época Helenística. Tanto la elección del plátano para el pórtico de Pompeyo, como la elección de un modelo de edificio cerrado por un cuádruple pórtico era semejante a los jardines de las palestras y de otros jardines griegos. Todo ello apunta claramente que el pórtico de Pompeyo está directamente relacionado con la tradición helenística oriental de los «paseos».

Las galerías de columnas que rodean un edificio o peristilos eran ya en época de Pompeyo una tipología generalizada. Sin embargo, la estructura de un espacio totalmente cerrado por pórticos y un jardín de árboles en

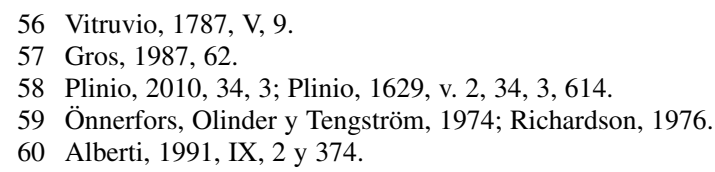


su interior era una recientísima novedad, incluso en el mundo griego del s. I a.C. El propio Vitruvio apuntaba cómo el modelo seguido en el pórtico de Pompeyo estaba vinculado con el pórtico ateniense de Eumenes, y con el viejo pórtico del Témenos de Dionisio, detrás del teatro de Atenas. ${ }^{61}$

Por lo tanto, los jardines públicos dados por Pompeyo a sus compatriotas no tienen nada que ver con la tradición italiana de jardín. Estos son una novedad traída por Pompeyo en sus viajes de conquista por el próximo Oriente. En el jardín helenístico del pórtico de Pompeyo también se crearon aulas destinadas a la enseñanza, construcciones que vamos a encontrar en los jardines privados, donde tomaron una gran importancia.

El ejemplo de Pompeyo fue seguido por Octavio Augusto y por sus colaboradores a quien Roma debió la existencia de la mayor parte de sus jardines públicos generalmente plantíos de árboles. Fue entonces cuando se limpió la parte central del Campo de Marte de Roma, con la ayuda del general y Edil Marco V. Agripa (63-12 a.C.), y se abrió al público el jardín del pórtico de Pompeyo, por el deseo de Augusto de regalar al pueblo de Roma, jardines dignos de un emperador como él. ${ }^{62}$

\section{La búsqueda de la herencia romana en los siglos del Renacimiento: acerca del orden de los jardines en los textos latinos clásicos}

Como hemos visto, conservamos un extraordinario conjunto de escritos sobre cultivos de árboles ornamentales, de gran calidad que se extiende durante novecientos años siendo el más antiguo del siglo $\mathrm{V}$ a.C. Son textos de distinto carácter que contienen reflexiones sobre la vida en contacto con la naturaleza vegetal ornamental, y su cultivo destinado a la contemplación estética y a la recreación. Por tanto están alejados de otros fines productivos agrícolas, y no reclamaban a esas especies más que belleza y disfrute para el hombre, sin demandar rentabilidad económica alguna.

Estos escritos clásicos han tenido un enorme valor para ayudar en la Edad Moderna a recuperar un nuevo interés por el cultivo de árboles y plantas ornamentales, coincidiendo con la nueva mentalidad renacentista. Junto con la nueva forma de entender la ciencia, el saber filosófico y estético, un nuevo y prometedor amanecer surgió buscando en la vida urbana el contac-

61 Vitruvio, 1787, «De los pórticos y paseos detrás de la escena», V, 9, 31, 125.

62 Grimal, 1984, 173. 
to con los árboles y la naturaleza, en ámbitos privados primero y públicos después, procurando con ellos el placer estético y la recreación entre árboles ornamentales, ordenados por el hombre generalmente con ayuda de una elemental geometría, en los nuevos proyectos de jardinería.

Los hombres del Renacimiento buscaron en los textos de escritores clásicos distintos relatos, algunos son interesantes descripciones de distinta longitud, otras obras completas concebidas como tratados técnicos o teóricos en los que se trata sobre las trazas del espacio de recreación de los jardines. En todos se manifestó un importante interés por el disfrute personal y por el cultivo de los árboles, dispuestos en conjuntos geométricamente ordenados y según los principios de la armonía, en todo caso buscando consecuencias muy positivas para el hombre en el contacto con la naturaleza. Es amplia la relación de textos procedentes de sabios filósofos griegos como Platón, Aristóteles o Teócrito, eruditos latinos como Catón el Censor, Varrón, poetas como Lucrecio, Catulo, Virgilio, Horacio, Ovidio, ilustrísimos literatos como Cicerón, o el enciclopedista Plinio el Viejo, y también de historiadores como Suetonio, y san Sidonio Apolinar. No obstante los principales tratadistas que aportaron información sobre jardines clásicos a los hombres del Renacimiento fueron Vitruvio y Columela. Todos ellos incluidos con acierto por Michel Baridon en distintas obras de compilación de fuentes sobre la jardinería en general, en los que analizó la rica información sobre jardines de todo tipo que nos han aportado los autores clásicos. ${ }^{63}$

A partir del siglo $\mathrm{XV}$, una nueva estética y nueva concepción del mundo de los jardines estuvo protagonizada principalmente por el humanista y arquitecto Leon Battista Alberti, y por los arquitectos Antonio Averlino il Filarete, Francesco di Giorgio Martini, Sebastiano Serlio y Andrea Palladio. Sus propuestas teóricas y técnicas para los jardines estuvieron basadas en la interpretación de los escritores clásicos de distinto tipo. En aquel conocimiento de los textos de la Antigüedad también colaboraron los dominicos Francesco Colonna y Agostino del Riccio.

No obstante, Leon Battista Alberti gracias a su extraordinario dominio del latín fue el primero en poder leer con gran aprovechamiento los textos clásicos que habían llegado al siglo XV, interpretarlos y explicarlos en su tratado De re aedificatoria, obra a la que se dedicó durante gran parte de su vida. Alberti creó un fundamento teórico para la arquitectura que no pudo ser superado en su totalidad por ninguno de sus contemporáneos, y

63 Baridon, 2004, I, 179-302. 
que constituye la obra clave de la recuperación de la arquitectura y de la jardinería clásica en Europa. Fue él quien difundió con claridad y conocimiento la herencia clásica sobre arquitectura y jardinería en Europa. En De re aedificatoria dedicó el libro IX a «La ornamentación de los edificios privados», y en esta parte, cuando hablaba de los posibles temas a tratar para los revestimientos del edifico y el acabado con pintura, recomendaba que, entre otros asuntos, en los edificios del jardín la decoración conveniente era las costumbres de la vida campesina:

será la más adecuada para los jardines, por ser la más alegre de todas. Lo que más nos alegra el espíritu es la contemplación de pinturas en las que figuren comarcas agradables... paisajes exuberantes de flores y de vegetación. ${ }^{64}$

En este mismo libro IX reunió la más rica información sobre los jardines que tuvo un largo interés en la recuperación de estos nuevos espacios de recreo tanto privados como los públicos, que comenzarán a realizarse desde mediados del siglo XVI en los reinos de los Habsburgo españoles y en Italia. En el capítulo IV da con claridad las claves del jardín, que orientaron en la nueva concepción de las alamedas urbanas y periurbanas de las ciudades de los Austrias como lugar que debe ser agradable y placentero, en el que se debe disfrutar de la sombra:

Habrá también jardines y plantas agradables, y en el jardín un pórtico desde el que puedas tomar el sol así como disfrutar de la sombra. Habrá también un espacio sumamente placentero. Surgirán inesperadamente cauces de agua de numerosos lugares. Setos de hoja perenne delimitarán los senderos. ${ }^{65}$

En las recomendaciones dadas para los jardines por Alberti dominan las referencias a un conjunto de árboles que se convertirán en los más tradicionales y repetidos de los jardines de Italia desde el silgo XV:

Y no faltarán cipreses cubiertos de hiedra. Se trazarán círculos, semicírculos y las figuras que convengan a las superficies de los edificios con el laurel, el cedro, el enebro con las ramas recogidas y mutuamente entrelazadas [...]. La vid, con la cual cubrían los senderos del jardín, los antiguos la colocaban sobre columnas de mármol. Dichas columnas tenían un espesor equivalente a la décima parte de su longitud, de orden corintio. ${ }^{66}$

64 Alberti, 1991, 380.

65 Ibidem, 380-381.

66 Ibidem, 381. 
A continuación Alberti en el tratado acudió a una copia libre de un texto las Epístolas, de Horacio, para ensalzar la sombra destinada a resguardar al amo y seguir estableciendo una diferencia clara entre los campos de cultivo y el jardín ornamental:

Dice el famoso poeta: Produzca la zarza cerezas silvestres y endrinas, y que la encina y el acebo procuren / abundante alimento al ganado, sombra en abundancia al amo*. Pero tales cosas puede que convengan más a las fincas hortofrutícolas que al jardín. ${ }^{67}$

Finalmente, Alberti al terminar de tratar la villa rural para comenzar a dar las características de la vivienda urbana, recomendaba otra de las características de su arquitectura, la de buscar la construcción de pórticos en los que era deseable que se pudiese disfrutar de una agradable vista, si era posible desde un lugar elevado:

La casa de ciudad, por otro lado, no les irá un ápice a la zaga en alegría a las fincas con jardín por lo que hace a sus partes interiores (salas de estar o comedores); pero en las exteriores, como es el caso del pórtico y del vestíbulo, no estarán dotadas de tanta alegría como para que dé la impresión de que se ha echado en olvido la seriedad. ${ }^{68}$

La información arbórea dada por Alberti será clave para definir las nuevas alamedas y los paseos flanqueados por árboles aportando dos interesantes recomendaciones. La primera es hacer plantíos de las hileras de árboles y la segunda, seguir una ordenación de acuerdo con los principios de la geometría, como se encuentra referido en la primera edición del tratado De Re Aedificatoria de 1485, donde recomienda la disposición en orden de quincunce, ${ }^{69}$ tradicional en las alineaciones de árboles romanas. Esto, unido a la forma habitual de los paseos en el mundo clásico, divididos en tres calles, contribuiría a perfilar el concepto general de la estructura de los paseos en forma de alameda:

Las hileras de árboles se colocan en línea, a igual distancia entre sí y con los ángulos en correspondencia, como se suele decir, al quincunce. ${ }^{70}$ Haremos que el jardín esté

67 Idem. El asterisco remite a esta nota a pie de página: «(N. del T.) Horacio, Epistolae, 1 16, 9-10. No es cita literal».

68 Idem.

69 Diccionario de la Real Academia de la Lengua: quincunce. (Del lat. quincunx, -cis) Disposición semejante a la figura de un cinco de dados, con cuatro puntos que forman rectángulo o cuadrado y otro punto en el centro.

70 «Arborum ordines ad lineam et interuallis comparibus et angulis correspondentibus, uti aiunt, ad quincunquem», Alberti, 1485, 163v, líneas 9-11. 
verde con hierbas raras, y con las que poseen propiedades medicinales. Me gusta la costumbre que entre los antiguos solieron tener los administradores, cual es la de agasajar a los amos trazando sus nombres en la superficie con boj o con plantas olorosas. La rosa formará un seto, estará entrelazada con los avellanos y los granados. ${ }^{71}$

En efecto, también un texto de Marco Fabio Quintiliano (ca. 35ca. 95 d.C.) nos dejó su opinión favorable a los árboles frutales frente a los ornamentales, además de indicar que incluso con ellos se podía alcanzar el orden y la geometría en las alineaciones siguiendo el quincunce:

\begin{abstract}
¿Por ventura tendré yo por mejor cultivada una tierra donde no se presenta a la vista lirios, violetas y manantiales de agua, que otra que está cargada de mies y llena de viñas? ¿Estimaré en más un plátano estéril y los arrayanes de ramas artificiosamente cortadas, que el olmo bien casado con la vid y la oliva que se desgaja por su mismo fruto? Dejemos aquellos árboles [ornamentales] para los ricos: aunque ¿cuáles serían sus riquezas si no tuvieran otra cosa?

Pues qué, ¿aun en los frutales no buscamos también el adorno juntamente con el fruto? ¿Quién lo niega? Pues también plantamos los árboles a cuerda y con cierto orden. $\mathrm{Y}$ si no ¿qué mejor vista que la de una quincunce que por donde quiera que se mire están todos los árboles en hilera? Pues aun esta disposición contribuye para que igualmente chupen el jugo de la tierra? [...]. De modo que la utilidad debe ir junta con la hermosura; pero esto lo discernirá cualquiera de mediano talento. ${ }^{72}$
\end{abstract}

\title{
El trazado regular del jardín público renacentista de árboles
}

La condición primordial del jardín renacentista de las alamedas era la regularidad de la composición, fundamentada en la geometría según se establecía en la tratadística. Estos espacios preferentemente rectangulares se creaban por la implantación de dos ejes perpendiculares sobre el plano horizontal, generalmente allanado. El trazado regular comprendía la forma rectangular del perímetro, y además líneas paralelas y la disposición ortogonal entre ellas, separadas por intervalos modulados. Para la implantación en espacios urbanos irregulares en ocasiones fue necesario dejar alrededor de la alameda unos márgenes libres que salvaban las irregularidades de las alineaciones de las fachadas limítrofes, como ocurrió en Sevilla en 1574.

71 Alberti, 1485, IX, 4; Alberti, 1991, 381.

72 «Quis negat? Nam et in ordinem certaque interualla redigam meas arbores. Quid enim illo quincunce speciosius, qui in quamcumque partem spectaueris rectus est?». Quintiliano, 1558, VIII, 3 y 430; Quintiliano, 1916, VIII, 38-39. 


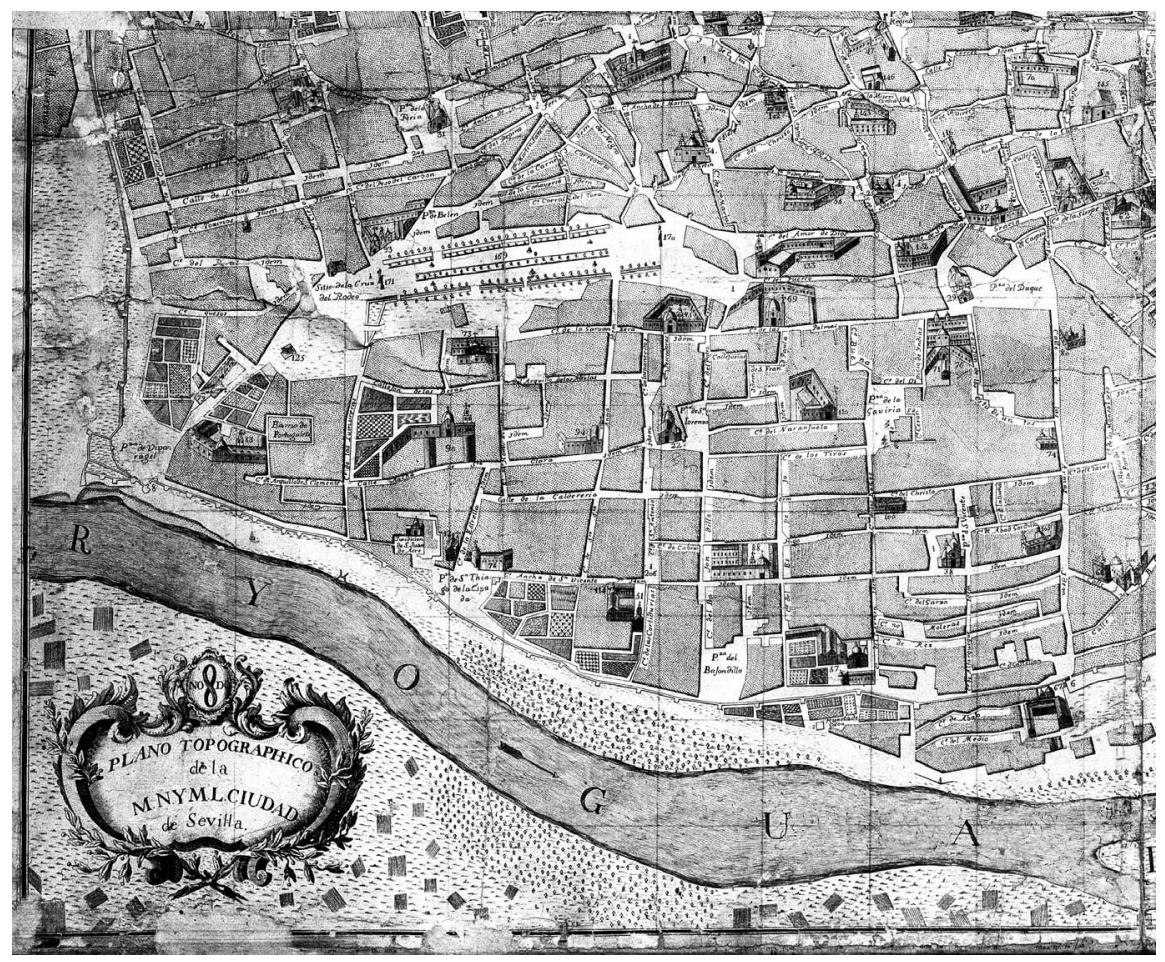

Figura 1.-Francisco Manuel Coelho (dib.), José Amat (grab.), Plano de Sevilla, 1771. Se levantó por disposición de Pablo de Olavide, asistente de la ciudad. Se puede observar la irregularidad de las alineaciones de fachadas colindantes, regularizadas con unos márgenes libres de ocupación.

La regularidad en el jardín se daba en los elementos principales que lo constituían: suelo, arquitectura, agua y vegetación. El terreno se nivelaba para dar uniformidad, la geometría regular también afectaba a la arquitectura del jardín y a la vegetación sujetada a alineamientos rectos de árboles. La distribución del agua se debía producir por acequias rectas, por el contrario las formas curvas o poligonales sólo se daban en las pilas o tazas de las fuentes.

La regularidad comprendía el eje axial del jardín, el cual dividía con una línea imaginaria central que enlaza todas las partes; y atravesaba la avenida principal y la portada de acceso, en caso de existir. La relación compositiva, como correspondencia entre ejes, seguía las recomendaciones 
teóricas dadas por la tratadística de Antonio Averlino il Filarete y Francesco di Giorgio Martini. La simetría axial era reforzada por las fuentes alineadas en el eje de simetría o distribuidas en pares simétricos en torno a él. Este eje de simetría aportaba una jerarquización de acuerdo a la proximidad o distancia respecto a la línea imaginaria ordenadora del conjunto. Por último, el núcleo normativo básico de la composición de las alamedas atendería a la buena proporción recomendada por Alberti en el libro I, 9, el de mayor contenido teórico del tratado de arquitectura, ${ }^{73}$ y que trata de cómo la buena proporción gobierna las relaciones de medida de las partes con el todo.

El trazado regular no era una excepción destinada en exclusiva para los jardines, pues entonces se estaba intentando pasar del urbanismo espontáneo de la ciudad medieval, a un urbanismo geométrico y racional expresado en la ciudad ideal de la tratadística. Palladio en su libro III,1, al hablar de las vías de la ciudad recomendada, abordó el interesante aporte ornamental de los árboles, el animoso efecto causado por ellos sobre los ciudadanos y la grata sombra que proporcionaban a todos:

E si come nelle Cittá si aggiogne bellezza alle vie con le belle fabriche; cosí di fuori si accresce ornamento a quelle con gli arbori, i quali, essendo piantati dall'una, e dall'altra parte loro, con la verdura allegrano gli animi nostri, e con l'ombra ne fanno commodo grandissimo. ${ }^{74}$

\section{Las alamedas urbanas}

Estos principios teóricos de la arquitectura del Renacimiento se pudieron materializar en las alamedas urbanas que fueron creadas en el siglo XVI como jardín público de árboles, destinadas al servicio de la recreación y el ornamento urbano. Tal tipo de jardín siempre estaba trazado regularmente mediante la plantación de hileras de grandes árboles de sombra. Entre ellos se elegían especialmente los álamos, los olmos y los tilos por lo que debían contar con abundante agua de riego. El concepto de alameda como modalidad de jardín público, era distinto de las alamedas naturales que crecían en los ríos y, diferente también de las alamedas plantadas por el hombre. Estas últimas tenían distintos fines como la producción de madera, o la

73 Alberti, 1485, I, 9; Alberti, 1991, 81.

74 Palladio, 1570, lib. III, 3. 


\section{LA ALAMEDA, UN JARDÍN PÚBLICO DE ÁRBOLES Y AGUA}

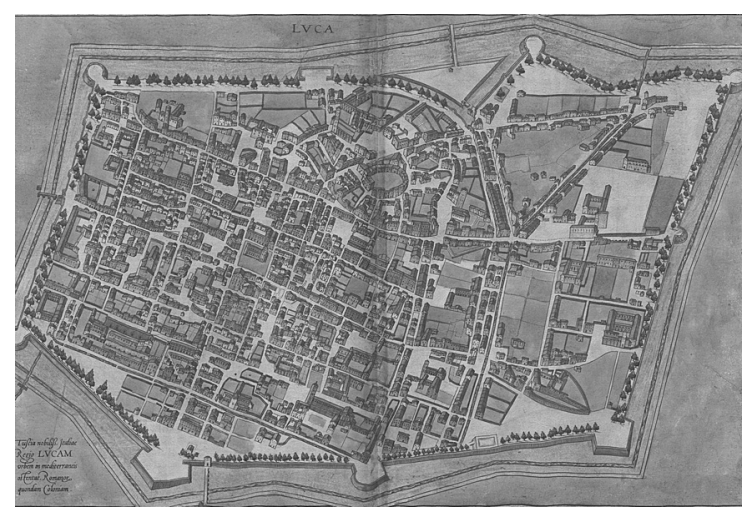

$1 .{ }^{\mathrm{a}}$

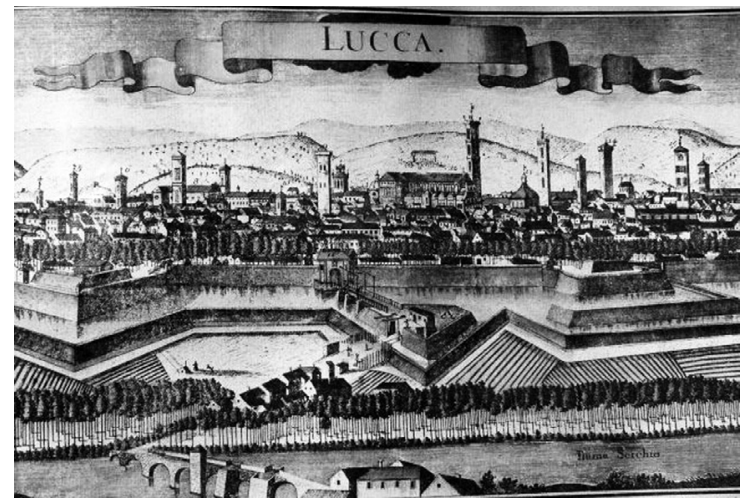

$2 .^{\mathrm{a}}$

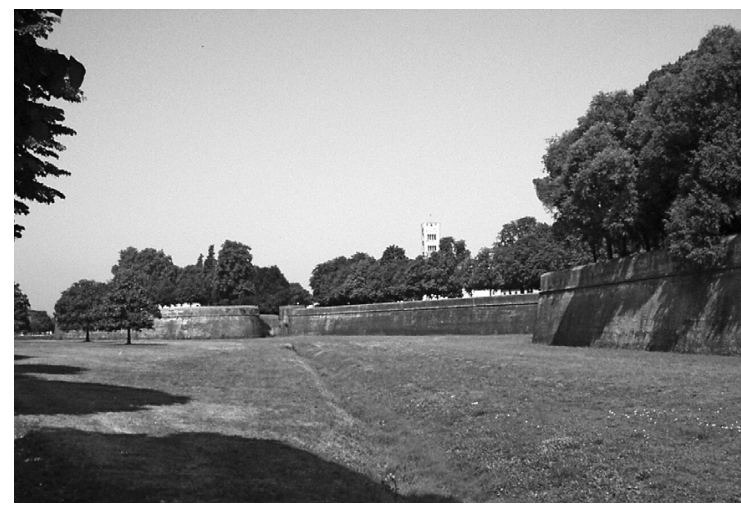

$3 .^{\mathrm{a}}$

FIGURA 2.-Las murallas renacentistas perimetrales de la ciudad de Lucca, entre torres se plantaron hileras de árboles en 1544. 1. ${ }^{\text {a }}$ ) Georg Braun y Franz Hogenberg, «Lucca», Civitates Orbis Terrarum, Colonia, 1617, vol. 4, 50. 2. ${ }^{a}$ ) F. B. Werner (dib.), Johann Friedrich Probst y Jeremias Wolff (dibs., eds.), «Lucca», ca. 1730. 3. ${ }^{a}$ ) Panorámica actual. 
contención de suelos en obras de ingeniería civil, generalmente construcciones en las orillas de los ríos o canales, en los pólderes holandeses y también con el mismo fin estabilizador se usaba en los lienzos de murallas como las de la ciudad de Lucca. En1544 se construyó el primer tramo de la nueva cortina de la muralla renacentista, entre los baluartes de San Colombano y de la Libertad, en la que se plantaron las primeras hileras de árboles en 1546. Los habitantes de Lucca de inmediato comenzaron a acudir a la nueva arboleda para sus paseos, tal y como Francesco Bendinelli escribió: «La prima piantata fece in breve una grandissima impressione a segno che il popolo tutto ne restò molto soddisfatto, per la comodità dello spasso che ne prendeva per passeggiarla come se fosse sua propria villa». ${ }^{75}$ Sobre la silvicultura es interesante la noticia aportada por Plinio el Viejo quien se hizo eco de que Gayo Macio, en época de Octavio Augusto, fue el primero en plantar bosques con fines productivos. ${ }^{76}$

En los estados de Flandes heredados por el Emperador Carlos V se conocía desde el siglo XII la técnica de estabilización de los márgenes de los pólderes. Se realizaban con alineaciones de árboles de raíz pivotante o primaria profunda, de géneros adecuados a vivir en terrenos pantanosos como los olmos. Las poderosas raíces servían para armar y dar solidez a las arenas de los pólderes a modo de profundos pilotes. Estos trabajos de consolidación en los diques generaron bellas arboledas, que, por lo menos desde el siglo XVI, se aprovecharon como paseos de recreación en verano.

El más interesante ejemplo lo conocemos en el centro de la ciudad de La Haya, en la orilla norte de la laguna artificial de Hofvijver, donde conservamos la más antigua alameda de la que tenemos noticia. Sobre un dique construido en el siglo XIV, formado con la arena extraída de la laguna y se fortaleció con la plantación de olmos que armaron el dique con sus poderosas raíces. En la actualidad se conserva en el mismo lugar una replantada alameda el Lange Vijverberg que igualmente sirve de contención al dique y de paseo vecinal.

Este paseo tiene continuidad en el Korte Voorhout, otra calle inmediata arbolada con cuatro hileras de tilos, mandado plantar por el emperador Carlos V después de su visita a La Haya en 1536. Estas últimas, como todas las demás alamedas hispánicas, tuvieron como precedente los caminos flanqueados por árboles; el arbolado daba sombra y aportaba belleza a los caminos desde la Antigüedad. Además, también fueron precedentes las

75 Martinelli y Puccinelli, 1983, 91.

76 Plinio, 1629, XII, 13; Plinio, 2010, v. 3, 20. 


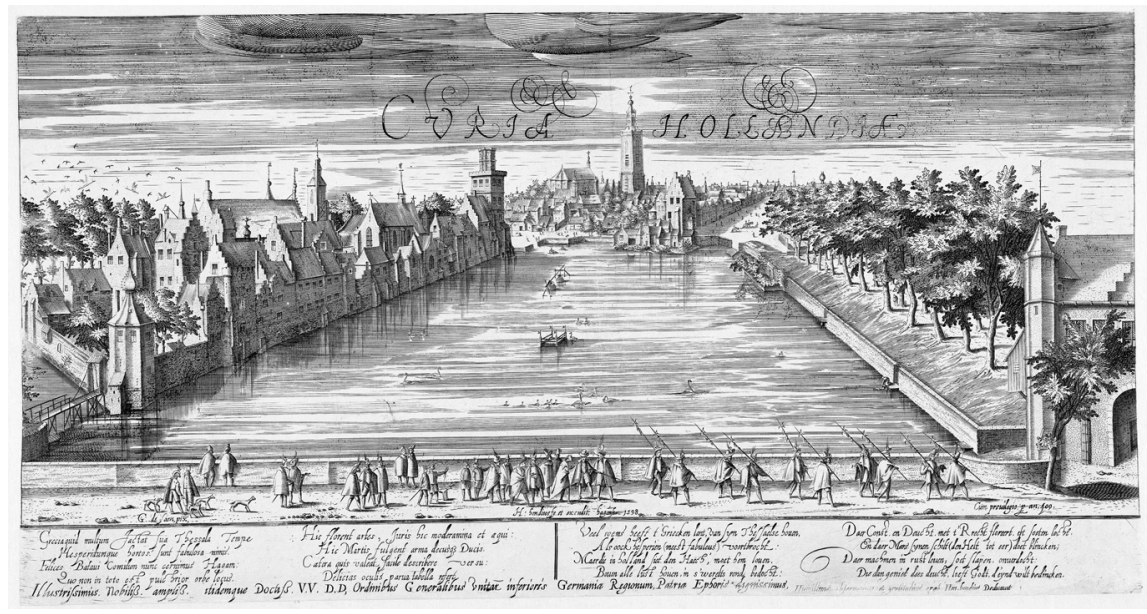

FIGURA 3.-Hendrik Hondius I, Vista del Vijverberg en La Haya, 1598. En el extremo derecho del estanque Hofvijver, el paseo Lange Vijverberg.

alineaciones de árboles que, con fines estructurales, se plantaron en los diques y en los lienzos de murallas de tierra apisonada desde la Edad Media, convertidos en agradables paseos.

Las características de estos bosquetes sobre los pólderes con fin utilitario, han sido vinculadas con las alamedas de la península ibérica, ${ }^{77}$ aunque a nuestro entender sin fundamento suficiente, pues en España, en pocos casos había que estabilizar los suelos de las alamedas con las raíces de los árboles. Sólo en las alamedas de ribera plantadas en zonas combatidas por las crecidas de los ríos tuvieron esa misión de consolidación con árboles de raíz principal poderosa, así ocurría en el paseo de la Magdalena de Valladolid, en la alameda de Córdoba o el paseo del León de Écija.

Como conclusión, podemos decir que quizá a partir de estas experiencias en Flandes y su consecuente uso como paseos surgieron las alamedas urbanas con fines ornamentales y de recreación en las ciudades de la península ibérica hacia 1550. Fueron estas los primeros jardines públicos urbanos del Renacimiento europeo, que revivían un espacio semejante a los rus in urbe de la antigua Roma. Según los datos conocidos hasta el momento, el Emperador Carlos V comenzó a financiar su construcción, pero sobre todo fue su hijo el rey Felipe II quien durante su reinado las promovió, y

77 Paya, 2014. 
con el estímulo real aparecieron en las ciudades prósperas más vinculadas a la corona..$^{78}$

Los nuevos conceptos urbanísticos de los Austrias incluían la incorporación de la naturaleza a los conjuntos urbanos y palaciales. El sustrato teórico en el que se apoyaban la presencia urbana de la naturaleza era que con ella se embellecía el espacio para gozarlo, asumiendo el papel de elemento estético. ${ }^{79}$ Con las alamedas la naturaleza pudo penetrar en la ciudad, como espacio destinado al paseo que aportaban a los humanos consecuencias físicas y psíquicas saludables.

A lo largo de la historia, los distintos jardines públicos han estado exclusivamente organizados con plantaciones arbóreas y arbustivas. Fueron concebidos como proyectos urbanísticos de progreso, puestos al servicio del disfrute de los habitantes de la ciudad, generando además una decoración ambiental.

En síntesis, ya desde la Antigüedad clásica los jardines públicos habían formado parte del patrimonio urbano. Y en efecto, con signos de continuidad los jardines públicos han aparecido en el comienzo de la prosperidad urbana, así se dieron en los conjuntos urbanos más avanzados primero en Atenas y más tarde en otras ciudades balcánicas. El nacimiento y vida de las alamedas como paseos públicos se unen al fenómeno clásico, y de nuevo en la Edad Moderna comenzaron a transformar los modos de vida y la imagen de los asentamientos urbanos. Justamente, con la recuperación del jardín público y los privados durante el siglo XVI se dieron una serie de características que anunciaban la transformación de la ciudad medieval en la ciudad moderna.

Por último, no fue hasta la Ilustración cuando se produjo la definitiva implantación de los jardines públicos contemporáneos en el contexto urbano, que estuvo íntimamente conectada con los procesos de progreso y embellecimiento promovidos por el nuevo movimiento ilustrado.

Recibido el 18 de junio de 2015 Aceptado el 20 de julio de 2015

78 Sigüenza, 1996, 66-68. No tenemos certeza sobre el papel desempeñado por el rey Felipe II en la promoción del paseo de la alameda de Hércules de Sevilla. Es posible que existiese una importante relación del monarca con el proyecto, según una fuente coetánea y de probada fiabilidad, como era el notario apostólico Francisco de Sigüenza, quien escribio lo siguiente sobre el origen de las trazas: «y más ilustre por haber su Magestad — según se tiene por cierto— dado orden y enbiado la traça de ella...». Albardonedo Freire, 1998, 136.

79 Cervera Vera, 1968, 176. 


\section{Fuentes literarias y tratados}

Alberti, Leon Battista: De Re Aedificatoria, Florencia, Nicolaus Laurentii, Alamanus, 1485.

Alberti, Leon Battista: De Re Aedificatoria, Javier Fresnillo Núñez (trad.), Madrid, Akal, 1991.

Catón, Marco Porcio: De agricultura o De Re Rustica, «Fundum suburbanum», I, 7-8.

Cicerón, Marco Tulio: Cartas. I Cartas a Ático (cartas 1-161D), M. RodríguezPantoja (trad.), Madrid, Gredos, 1996.

Columela, Lucio J. M.: L. Inni Moderati Columellae Res rustica; incerti auctoris Liber de arboribus, R.H. Rodgers (ed.), Oxford, Oxford University Press, 2010.

Diógenes Laercio: «III Platón», en Vidas, opiniones y sentencias de los filósofos más ilustres.

Estrabón: Geographica, VIII.

Honorato, Mauro Servio: In Vergilii Bucolica commentarii, Ecl. 7.61, en Servio Honorato, In Vergilii carmina comentarii. Servii Grammatici qui feruntur in Vergilii carmina commentarii; recensuerunt Georgius Thilo et Hermannus Hagen, Georgius Thilo, Leipzig, B. G. Teubner, 1881.

Livio, Tito: Ab Urbe Condita, II.

Palladio, Andrea: I quattro libri dell'architettura, Lib. III, I, Venecia, Domenico de Franceschi, 1570.

Pausanias: Periegesis tes Hellados, V.

Platón: Leyes, J. M. Ramos Bolaño (ed.), Madrid, 1988.

Platón: Fedro, Emilio Lledó (trad.), Barcelona, Planeta, 1995.

Plinio Segundo «el Viejo»: Historia Natural, Jerónimo de Huertas (trad.), Madrid, 1629.

Plinio Segundo «el Viejo»: Historia Natural, F. Manzanero Cano et al. (trad.), Madrid, Ed. Gredos, 2010.

Plutarco, Lucio Mestrio: «Vida de Cimón», en Vidas Paralelas, José Alsina (ed.), Antonio Ranz Romanillos (trad.), Barcelona, Planeta, 1990.

Plutarco, Lucio Mestrio: «Vida de Lúculo» y «Vida de Publicola», en Vidas Paralelas.

Quintiliano, Marco Fabio: Institvtionvm oratoria, Lyon, Theobaldun Paganun, 1558.

Quintiliano, Marco Fabio: Instituciones Oratorias, Ignacio Rodríguez y Pedro Sandier (trads.), Madrid, Imp. Pelardo Páez y Cía., 1916.

Séneca, Lucio Anneo: Ad Lucilium, IV.

Sigüenza, Francisco: Traslación de la imagen de Nuestra Señora de los Reyes... (1579), Federico García de la Concha Delgado (trans. y ed.), Sevilla, Fundación El Monte, 1996.

Teofrasto: Historia de las plantas, José María Díaz-Regañón López (trad.), Madrid, Gredos, 1988. 
Varrón, Marco Terencio: De re rustica, I.

Virgilio Marón, Publio: Eneida, VIII.

Vitruvio, Marco: Los diez libros de arquitectura, José Ortiz y Sanz (trad.), Madrid, Imprenta Real, 1787.

\section{Bibliografía}

Aguilar Diosdado, Abilio y García León, Gerardo: Reseña histórica del Paseo de San Pablo, Écija, Ayuntamiento de Écija, 1988.

Albardonedo Freire, Antonio: «Las Trazas y Construcciones de la Alameda de Hércules», Laboratorio de Arte, 11, Sevilla, 1998, 135-165.

Albardonedo Freire, Antonio J.: «Carlos V en la Alameda de Sevilla», en El Emperador Carlos V y su tiempo. Actas de las IX Jornadas Nacionales de Historia Militar, Sevilla, Deimos, 2000, 901-920.

Albardonedo Freire, Antonio J.: El Urbanismo de Sevilla durante el reinado de Felipe II, Sevilla, Guadalquivir Ediciones, 2002.

Albardonedo Freire, Antonio J.: «La Alameda de Úbeda», en prensa.

Baridon, Michel: Los jardines: paisajistas, jardineros, poetas. Antigüedad, Extremo Oriente, Madrid, Abada Editores, 2004.

Bengtson, Hermann (comp.): Griegos y persas. I. El mundo mediterráneo en la Edad Antigua, Madrid, Siglo XXI, 1972.

Brandis García, Dolores: «La construcción y difusión de imágenes del Paseo del Prado de Madrid en los relatos de viajes», en Espacios y destinos turísticos en tiempos de globalización y crisis, I, Madrid, AGE-Grupo TERAP, Universidad Carlos III, 2011, 169-185.

Carroll-Spillecke, Maureen: «The Garden of Greece from Homeric to Roman Times», The Journal of Garden History, 12-2, Londres, 1992, 84-101.

Castro Morales, Efraín: Alameda Mexicana. Breve crónica de un viejo paseo, México, Museo Mexicano, 2004.

Cervera Vera, Luis: «La época de los Austrias», en García Bellido, Antonio et al., Resumen histórico del urbanismo en España, Madrid, Instituto de Estudios de la Administración Local, 1968, 173-209.

Contreras y López de Ayala, Juan de, Marqués de Lozoya: «El conjunto arbolado y alameda de Segovia», Academia: Boletín de la Real Academia de Bellas Artes de San Fernando, 39, Madrid, 1974, 104.

Duarte, María Estela; Sánchez, Américo y Ugalde, Nadia: Alameda: visión histórica y estética de la Alameda de la Ciudad de México, México, INBA, 2001.

Durán Montero, María Antonia: «La Alameda de los Descalzos de Lima y su relación con las de Hércules de Sevilla y la del Prado de Valladolid», en Andalucía y América en el siglo XVII. Actas de las III Jornadas de Andalucía y América, Escuela de Estudios Hispano-Americanos, 1985, t. 2, 171-182. 
Fernández Chaves, Manuel: Política y administración del abastecimiento de agua en Sevilla durante la Edad Moderna, Sevilla, Diputación Provincial, 2012.

Gagliardo, Maria C. y Packer, James E.: «A New Look at Pompey's Theater: History, Documentation, and Recent Excavation», American Journal of Archaeology, 110-1, Boston, Archaeological Institute of America, 2006, 93-122.

Giusti, Maria Adriana: «Lucca: I giardini nelle mura-giardino», en Giusti, M.A., Acidini Luchinat, C. y Galletti, G. (eds.), Il giardino e le mura. Ai confini fra natura e storia. Atti del Convegno di Studi, S. Miniato Alto (Pisa), 23-24 giugno 1995, Serie Giardini, Citta, Territorio, 13, Firenze, Edifir Edizioni, 1997, 57-80.

Gothein, Marie Luise: Geschichte der Gartenkunst (1914), Nueva York, Haceker Art Books, I, 1979.

Grimal, Pierre: Les jardins romains. Essai sur le naturalisme romain, París, De Boccard, 1944. 3. a ed., París, A. Fayard, 1984.

Gros, Pierre: Architettura e società nell'Italia romana, Roma, A. Curcio, 1987.

Herrera, José Emilio: «Un relicario de recuerdos históricos quiteños: la Alameda», Cultura: Revista del Banco Central del Ecuador, 20, Quito, 1984, 393-398.

Jashemski, Wilhelmina F.: The gardens of Pompei, Herculaneum and the villas destroyed by Vesuvius, New Rochelle, Nueva York, Caratzas Bros, 1979.

Launey, Marcel: «Le verger d'Héraklès à Thasos», Bulletin de Correspondance Hellénique, 61, Paris, 1937, 380-409.

Lawrence, Henry W.: City Trees: A Historical Geography from the Renaissance through the Nineteenth Century, Charlottesville, University of Virginia Press, 2008.

Lleó Cañal, Vicente: Nueva Roma: Mitología y humanismo en el Renacimiento sevillano, Sevilla, Diputación Provincial, 1979.

Lopezosa Aparicio, Concepción: «Un singular edificio del Prado Viejo de San Jerónimo: La torrecilla de música», Anales de Historia del Arte, 5, Madrid, 1995, 93-100.

Lopezosa Aparicio, Concepción: El Paseo del Prado de Madrid. Arquitectura y desarrollo urbano en los siglos XVII y XVIII, Madrid, Fundación de Apoyo a la Historia del Arte Hispánico, 2005.

Lopezosa Aparicio, Concepción: «Paseos por la imagen de lo cotidiano un contexto para múltiples realidades», Congreso Internacional Imagen Apariencia, Universidad de Murcia, 19-21 de noviembre de 2008. Disponible en http://congresos.um.es/imagenyapariencia/imagenyapariencia2008/paper/ viewFile/2411/2361

Marcos Casqueiro, Manuel Antonio: «El exótico culto a Hércules en el Ara Máxima», Revista de Estudios Latinos, 2, Madrid, 2002, 65-105.

Martinelli, Roberta y Puccinelli, Giuliana: Lucca. Le Mura del Cinquecento. Vicende construttive dal 1500-1650, Lucca, Matteoni, 1983. 
Moreno Mendoza, Arsenio: «La alameda, un lugar de desahogo y recreación», en Urbanismo en la Úbeda del siglo XVI: entre la tradición medieval y la reforma, Jaén, Instituto de Estudios Giennenses, 2005, 211-222.

Moya del Baño, Francisca y Gallego Moya, Elena: «La Epístola 41 de Séneca traducida por Quevedo y defendida por él de "los ataques" de Muretus», en Hernández González, Fremiot; Martínez Hernández, Marcos y Pino Campos, Luis Miguel (eds.), Sodalivm Mvnera. Homenajea Francisco González Luis, Madrid, Ediciones Clásicas, 2011, 412-438.

Muñoz Rebolledo, María Dolores e Isaza, Jean Luis: «Naturaleza, jardín y ciudad en el Nuevo Mundo», Theoria, 10, Universidad del Bío-Bío, 2001, 9-22.

Önnerfors, Alf; Olinder, Björn y Tengström, Emin: Porticus Octavia in Circo Flaminio: topographical studies in the Campus region of Rome, Roma, Svenska Institutet i Rom, 1974.

Panzini, Franco: Per i piaceri del popolo. L'evoluzione del giardino publico in Europa dalle origini al XX secolo, Bolonia, Zanichelli Ed., 1993.

Pareja Delgado, María Josefa: «El abastecimiento urbano en Baeza y Úbeda en la Baja Edad Media», en Cara Barrionuevo, Lorenzo (coord.), El agua en zonas áridas. Arqueología e historia. Hidráulica tradicional de la provincia de Almería, Almería, Instituto de Estudios Almerienses, 1989, 813-836.

Paya, Laurent: «Les alamédas de l'Empire Espagnol durant la Renaissance: un ensemble singulier et cohérent de promenades arborées», Le Verger Bouquet 05, Tours, janvier 2014, 1-19. https://hal-univ-tours.archives-ouver tes.fr/halshs-00946791/

Ramallo Asensio, Sebastián F.: «La porticus post scaenam en la arquitectura teatral romana. Introducción al tema», Anales de Prehistoria y Arqueología, 16, Murcia, 2000, 87-120.

Richardson, Lawrence Jr.: «The Evolution of the Porticus Octaviae», American Journal of Arqueología, 80-1, Boston, 1976, 57-64.

Segawa, Hugo: «Alamedas e passeios na América Colonial», Anais. Seminário de História da Cidade e do Urbanismo, 8-2, Niterói, 2004. http://unuhospeda gem.com.br/revista/rbeur/index.php/shcu/article/view/972/947

Solís de los Santos, José: «El trasfondo humanista de la Alameda de Sevilla», Calamvs Renascens, 13, Alcañiz, 2012, 75-138.

Thompson, Dorothy Burr: «The garden of Hephaestus», Hesperia. The Journal of the American School of Classical Studies at Athens, 6-3, 1937, 396-425.

Uceda Ureña, Alfredo y Peragón López, Clara E.: «Viajes y viajeros en Baeza a finales del Siglo XVIII. Aproximación artístico-literaria», Imafronte, 17, Murcia 2003, 229-249.

Van Den Berg, Eva: «Un paseo por la historia segoviana: Alameda de Segovia», Biológica. Conocer y conservar la naturaleza, 54, Madrid, 2001, 76-77.

Veiga, Tomé Pinheiro da: Fastigina o fastos geniales (1605), trad. y notas de Narciso Alonso Cortés, Valladolid, Servicio de Publicaciones del Ayuntamiento, 1973. 